\title{
Relationship between environmental management policy and the local wisdom of indigenous peoples in the handling of COVID-19 in Indonesia
}

OÑATI SOCIO-LEGAL SERIES VOLUME 11, ISSUE 3 (2021), 860-882: INVESTIGATIONS - INVESTIGACIONES - IKERLANAK

DOI LINK: HTTPS://DOI.ORG/10.35295/OSLS.IISL/0000-0000-0000-1193

RECEIVED 26 OCTOBER 2020, ACCEPTED 09 FEBRUARY 2021

\section{WAHYU NUGROHO* (D)}

\section{Abstract}

This paper aims to understand the concept of local wisdom (Indonesian term: kearifan local) from the perspective of Indonesian indigenous peoples (Indonesian term: masyarakat adat) in handling COVID-19 and environmental management policies. In this article, use normative legal research methods, empirical data based on developments in policy and media in Indonesia, and qualitative analysis. The findings of this study are first, constructing local wisdom of Indonesian indigenous peoples in environmental management and handling of COVID-19, based on the teachings of their ancestors and based on the customary calendar as a reference; second, build partnerships related to environmental policies and indigenous peoples by considering the balance of nature and changes in human behavior through local wisdom to reduce carbon emissions during a pandemic. The author is interested in this research because there is an integration of local wisdom of Indonesian indigenous peoples in environmental policies and handling COVID-19.

\section{Key words}

Policy; environmental management; local wisdom; indigenous peoples; COVID19

\section{Resumen}

Este artículo se propone entender el concepto de saber local (término en indonesio: kearifan local) desde la perspectiva de los pueblos indígenas indonesios (término en indonesio: masyarakat adat) para gestionar la COVID-19 y las políticas medioambientales. En el artículo, se usan métodos normativos de investigación jurídica,

\footnotetext{
${ }^{*}$ Lecturer at the Faculty of Law, Sahid University of Jakarta, interested in the fields of environmental law \& policy studies, state administrative law, customary law, and human rights. Affiliated Sahid University of Jakarta, Jl. Prof. Dr. Supomo, SH No. 84 Tebet, South Jakarta, Indonesia 12870. Email address: wahyulaw86@yahoo.com
} 
datos empíricos basados en los desarrollos de políticas y medios en Indonesia, y análisis cualitativos. Los hallazgos del estudio son, primero, la construcción del saber local de los pueblos indígenas indonesios en gestión medioambiental y manejo de la COVID-19, basándose en las enseñanzas de sus antepasados y en el calendario consuetudinario; segundo, la construcción de alianzas relacionadas con políticas ambientales y pueblos indígenas, considerando el equilibrio entre naturaleza y cambios en el comportamiento humano a través del saber local para reducir las emisiones de carbono durante una pandemia. El autor se ha interesado en esta investigación porque existe una integración del saber local de los pueblos indígenas indonesios en las políticas medioambientales y la gestión de la COVID-19.

\section{Palabras clave}

Política; gestión medioambiental; saber local; pueblos indígenas; COVID-19 


\section{Table of contents}

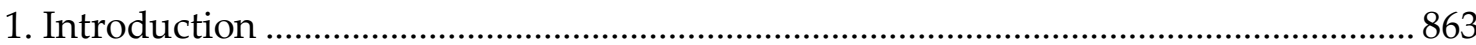

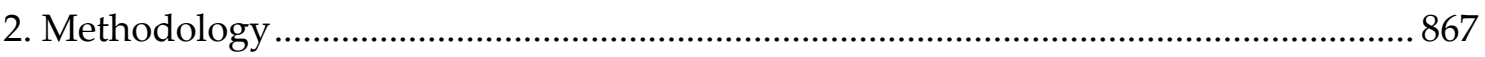

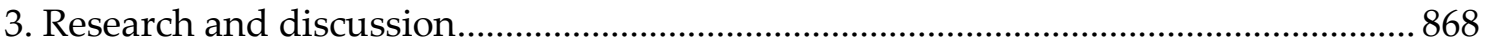

3.1. The concept of local wisdom from the perspective of indigenous Indonesians in environmental management and handling of COVID-19

3.2. The relationship between environmental management policy and local wisdom of indigenous peoples during the COVID-19 pandemic in Indonesia ..... 873

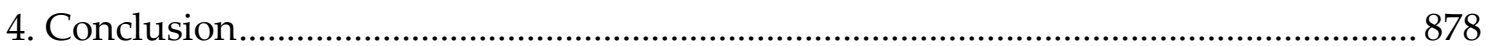

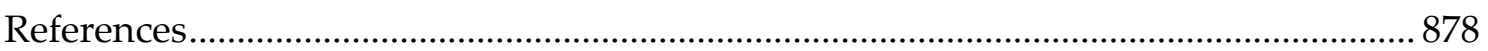




\section{Introduction}

Indonesia's environmental management policy based on Law Number 32 of 2009 concerning Environmental Protection and Management is influenced by global environmental developments that are oriented towards environmental utilization (Jazuli 2015, 187). Most legal scholarship increasingly suggests that the central problem of environmental law is its anthropocentrism. By simple reference to the literal meaning of the word, anthropocentrism indicates the centrality of human beings in the world (De Lucia 2017). The classical environmental law style is very anthropocentric, views the environment as a commodity so that the economic development of a country is very dependent on natural resources which have an impact on environmental damage or pollution. Indonesia has local wisdom that comes from the customary laws of indigenous peoples. ${ }^{1}$ Environmental management policy in Indonesia during the COVID-19 pandemic still used formal methods through legal products and legislation but had not involved indigenous peoples through local wisdom that each region had in environmental management. The state still places indigenous peoples and local wisdom as something mundane, or non-scientific, which is why it has been underestimated by the government.

The existence of indigenous peoples has constitutionally gained legitimacy and recognition by the state through Article 18B paragraph (2) of the 1945 Constitution, which in essence there is state recognition and respect for various customary law community units and their traditional rights following community development, while Article 28I paragraph (3) The 1945 Constitution emphasizes the aspect of respecting the cultural identity and rights of traditional communities following the existing dynamics of civilization and is confirmed in the Decree of the People's Consultative Assembly of the Republic of Indonesia (MPR Decree) Number IX / MPR / 2001 concerning Agrarian Reform and Management of Natural Resources.

The COVID-19 pandemic provides a lesson for people around the world about the importance of balance in the relationships between existing ecosystems. Humans with anthropocentric characteristics will use all their power to exploit natural resources for human profit, even if it entails the risk of extinguishing biodiversity. Regulations regarding local wisdom as part of the cultural identity of traditional communities and the right to the environment are adopted into the Indonesian constitution, namely Article 28I paragraph (3) of the 1945 Constitution, which states: “Cultural identity and

\footnotetext{
${ }^{1}$ Until now, the concept of indigenous peoples in Indonesia still has no agreement in its formulation, the reasons are first, there is no law that builds on the recognition and protection of indigenous peoples, while what exists is the variety of terms and criteria used by statutory regulations, secondly, in the Indonesian constitution Article 18B paragraph (2) of the 1945 Constitution uses the term "customary law community unit", and other terms are contained in Article 28I paragraph (3) of the 1945 Constitution by mentioning "traditional society". This then becomes a problem in the provisions of the derivative laws and regulations with different conceptual boundaries. Yance Arizona (2014) has provided guarantees for indigenous peoples and indigenous peoples that are more situated than the origin and purpose of use. The term "adat law community" was used by the colonial government to refer to a legal subject of the original composition of the indigenous community, while "adat community" was used by non-governmental organizations to refer to village people who firmly adhered to traditions, but who were victims of the New Order development. The differences between customary law communities and traditional communities in the 1945 Constitution occur because of the completion of their protection. Customary law communities to protect communities and control over land and natural resources, traditional communities to protect local identities.
} 
rights of traditional communities are respected in accordance with the development of times and civilization". The word cultural identity in question is local wisdom possessed by customary law communities and traditional communities. Regarding the right to the environment, it is regulated in Article 28H (1) of the 1945 Constitution, which states: "Everyone has the right to live in physical and mental well-being, to have a place to live, and to have a good and healthy living environment and the right to obtain health services".

This constitutional foundation in relation to local wisdom in environmental management is further regulated in Law Number 32 of 2009 concerning Environmental Protection and Management. The definition of local wisdom according to Law Number 32 of 2009 concerning Environmental Protection and Management is noble values that apply in the order of community life to, among others, protect and manage the environment in a sustainable manner. Based on the provisions in the constitution and the law on environmental management, it is important to carry out integration environmental management policies with local wisdom of indigenous peoples in handling COVID-19 in Indonesia. Various forms of local wisdom of indigenous peoples in a number of regions in Indonesia have a balanced pattern in protecting ecosystems and nature, so the government needs to build partnerships with indigenous peoples in handling COVID-19. This concept is the harmonization of the national legal system with the customary law system, besides that, it also reflects the value of unity that is connected in Pancasila with the slogan "Bhinneka Tunggal Ika" (unity in diversity) as the symbol of Garuda Pancasila. In the formation of law and its implementation based on the Indonesian national legal system, it should be adjusted to customary law as the living law in society, and pay attention to legal diversity or what is known as the legal of pluralism.

Every administrative law in Indonesia, particularly those of the management of natural resources, follows this pattern of policy. Even, the Second Amendment to the Basic Law of 1945 follows such model by stipulating the idea that "the State acknowledges jural communities and their traditional rights as long as they still live and by advancements in the society and the principle of Unitary state of the Republic Indonesia, to be further stipulated by law". Law Number 5 Year 1960 on the Basic Regulation of the Essentials of Agrarian Affairs (or more renowned, and subsequently called as the Basic Agrarian Law (BAL), adat law is recognized "as long as in reality still exist" and "does not in conflict with the State interest". However, the continuing process of the agrarian reform of 1960 seems to face some obstacles, such as a conflict between traditional rights and the modern, Western-influenced, various interests and purposes of the state (Priambodo 2018, 141).

In a constitutional state based on Pancasila, ${ }^{2}$ the environment becomes an inseparable part of the divine dimension and living things as well as natural elements as God's

\footnotetext{
2"Pancasila" consists of "Panca" and "Sila". "Panca" means "five", and "sila" means "principle" or "basis". Pancasila as the ideology of the Indonesian nation and state, which is stated in the preamble to the 1945 Constitution as the basis for the Unitary State of the Republic of Indonesia must be implemented continuously in the life of the nation and state. The Pancasila mentioned in the preamble to the 1945 Constitution are: first, Almighty Godhead, second, Just and Civilized Humanity, third, Indonesian Unity, fourth, Democracy Led by Wisdom in Deliberation/Representation, and fifth, Social Justice for All People of Indonesia.
} 
creation. The administration of a state that is based on values derived from the cultural roots of the Indonesian people with a variety of local wisdom is considered important to integrate environmental policy with local wisdom during the COVID-19 pandemic so that the principles of indigenous peoples in Indonesia become an integral part of national environmental policy. For example, based on empirical data that the author obtained by involving the participation of indigenous peoples in environmental management policies, and handling of COVID-19 through the "principles of religious magic and the balance of nature" as a form of their respect for God and nature by performing various traditional rituals, based on the teachings of their ancestors, so that wisdom It is important to integrate the local community into environmental management policies and the community is aware of the importance of maintaining the balance of nature, ecosystems, and environmental sustainability.

The concept of a Green Constitution that elevates the ecocracy in the constitution of a country is reflected in environmental sovereignty by placing the Green Constitution in the constitution of a country, making it an essential and fundamental foundation to uphold the development of human rights development currently developing (Atmadja 2006, Yusa and Hermanto 2018, 10). The concept of ecocracy is an environmental or ecosystem sovereignty where the government in running the government adheres to the principles of ecologically sustainable development. In the Indonesian context, the concept of ecocracy has been explicitly stated in the amendments to the constitution of Article $28 \mathrm{H}$ paragraph (1), ${ }^{3}$ and Article 33 paragraph $(4)^{4}$ of the 1945 Constitution, as an effort to prioritize sustainable development with an environmental perspective in the politics of national development.

Economic development that is in line with the principles of environmental insight and sustainability is an ideal conception of a democracy that upholds the principles of sustainable development so that economic rights are aligned with the right to a good and healthy environment as part of human rights in the third generation. The relationship between humans and natural resources, there will be excessive use of natural resources or exploitation for common interests, which then creates various social problems. Elinor Ostrom opposed proposals for privatization of Common Pool Resources (CPRs) or governmental intervention to avoid the tragedy of the commons. Instead, she suggested an alternative solution based on in-depth empirical studies, which was the establishment and operation of autonomous institutions within communities. Ostrom determined eight design principles for autonomous management of CPRs (Ostrom 1990, Forsyth and Johnson 2014, Choe and Yun 2017): 1. Define clear group boundaries, 2. Match rules governing use of common goods to local needs and conditions, 3 . Ensure that those affected by the rules can participate in modifying the rules, 4. Make sure the rule-making rights of community members are respected by outside authorities, 5. Develop a system, carried out by community members, for monitoring members' behavior, 6 . Use graduated sanctions for rule violators, 7 . Provide accessible, low-cost means for dispute resolution, and 8. Build responsibility for

\footnotetext{
${ }^{3}$ Stated that: "Everyone has the right to live in physical and spiritual prosperity and to have a place live and have a good and healthy environment, have the right get health services".

${ }^{4}$ Stated that: "The national economy is organized based on economic democracy with the principles of togetherness, efficiency-justice, sustainability, environmentally friendly, independence, as well as by maintaining a balance of progress and unity national economy".
} 
governing the common resource in nested tiers from the lowest level up to the entire interconnected system.

The complexity of environmental problems in the third generation of human rights often clashes with policy, both central and local. This policy is related to national strategic projects in the use of natural resources as raw material for national economic development so that there is a contradiction between human rights in the environmental sector and development. Sustainable development requires equitable resource management, both economically, socially, and environmentally for the current and future generations (Iskandar 2011).

In this paper, the scope of discussion is related to the concept of the relationship between environmental management policy and local wisdom of indigenous peoples in handling COVID-19 in Indonesia. The concept of local wisdom from the perspective of Indonesian indigenous peoples in environmental management and handling of COVID-19, and providing policy concepts for environmental management through local wisdom of indigenous peoples during the COVID-19 pandemic in Indonesia. Indonesia has the local wisdom of each region in handling COVID-19 which should be transformed into environmental management policy through local wisdom. One of the sub fields of environmental law is about environmental health law, and the law of human relations with the environment and nature, to create good relationships between communities of living things in the life of natural ecosystems.

The balanced relationship between man, God, and the universe is a principle inherent in all customary laws throughout Indonesia, so humans must maintain a legal relationship with God and the natural environment. These customary law principles are in the form of religious magic, participant cosmic and common. One example is the practice of customary law in most parts of the islands of Kalimantan and Papua, where the community performs customary rituals every time they open land for customary forest areas to be managed, and every time there is a violation of customary law among the members of the customary community cut down trees in the customary forest, there is a natural imbalance and the environment, so that it must be restored through customary rituals and given customary sanctions in accordance with the teachings of the ancestors.

Environmental management policy through local wisdom during the COVID-19 pandemic is a major issue because it is to restore the balance between humans and nature and the environment. This is motivated by the disharmony of the relationship between humans and ecosystems and nature, excessive exploitation of natural resources, resulting in environmental damage, and the extinction of biodiversity. During the COVID-19 pandemic, it became a reflection for the Indonesian government to restore the ecosystem and natural environment through various forms of local wisdom in some areas during the COVID-19 pandemic. Indigenous peoples as legal subjects have their philosophy and value system in viewing the natural environment. In Indonesian environmental law philosophy, there are various elements found in Pancasila, including the unity of divine, humanitarian, and diversity values.

Indigenous peoples as legal subjects are stated in the Indonesian constitution Article 18B paragraph (2) of the 1945: "The state recognizes and respects indigenous peoples and their traditional rights as long as they are alive and in accordance with the development of society and the principles of the Unitary State of the Republic of Indonesia. which is 
regulated in law". Indigenous peoples as legal subjects can be found in the decision of the Indonesian Constitutional Court Number 35 / PUU-X / 2012 in the Judicial Review of Law Number 41 of 1999 concerning Forestry, the Constitutional Court Panel of Justices using constitutionalism in the quote:

... in that constitutional provision, there is one thing that is important and fundamental in the traffic of legal relations, namely indigenous peoples who are constitutionally recognized and respected as rights holders, which of course can also bear obligations. Thus, indigenous peoples are legal subjects.

The panel of constitutional judges views that as a legal subject, the freedom and independence of indigenous peoples to determine their will and fulfil their basic rights is threatened by the provisions of the forestry law which place customary forests as part of state forests. Customary law communities, which existed even before the establishment of the Indonesian state, have the same status as other individuals or groups, namely as legal subjects. Simarmata and Steni call it a "special legal subject" because it can carry out public legal acts, the rights of indigenous peoples as legal entities come from innate rights, and members of the indigenous peoples are merged into the Joint identity so that it is natural. (Simarmata and Steni 2017).

An environment is a place for ecological communities and the elements of inanimate objects in it as life support, where God the Creator of the universe has absolute power, while humans have relative power, including protecting the earth for the continuity of life so that damage does not occur on land or in the oceans. From an environmental perspective, the emergence of COVID-19 is a form of human behavior that has no ethics towards other living things and exploitative actions against natural resources, resulting in an imbalance of relationships between communities in natural ecosystems, so that it becomes an important design principle for the management of commons.

The problems in this article are: first, what is the concept of local wisdom from the perspective of indigenous peoples in the Indonesian customary law system in environmental management and handling of COVID-19?; second, how is the relationship between environmental management policy through local wisdom of indigenous peoples in handling COVID-19 in Indonesia?

The purpose of writing this article is: first, to understand the concept of local wisdom from the perspective of Indonesian indigenous peoples in environmental management and handling of COVID-19, then can it be transformed into Indonesian environmental policy?; second, to formulate the concept of the relationship between environmental management policy and local wisdom of indigenous peoples in handling COVID-19 in Indonesia.

\section{Methodology}

In writing this article, using normative legal research methods, literature as secondary sources, and supported by empirical data based on policy developments and information media in Indonesia. This method is a combination of theory and policy with practices that develop in society, to get a complete picture of environmental management policy and handling of COVID-19 based on local wisdom. Data analysis used qualitatively by linking debates in the review literature and developing policy. 


\section{Research and discussion}

\subsection{The concept of local wisdom from the perspective of indigenous Indonesians in} environmental management and handling of COVID-19

Each community has local wisdom, traditional wisdom, local knowledge, or local intelligence and indigenous wisdom that is useful in life (Sinapoy 2018). Local wisdom is defined by Alfian as a view of life and knowledge as well as a life strategy in the form of activities carried out by local communities in meeting their needs. Local wisdom is a custom and custom that has been traditionally carried out by a group of people from generation to generation which is still maintained by certain customary law communities in certain areas (Alfian 2013).

Based on the above understanding, it can be interpreted that local wisdom can be understood as local ideas that are wise, full of wisdom, of good value, which are embedded and followed by members of the community. The meaning of local wisdom is conceptualized as "local wisdom" or "local knowledge" (Fajarini 2014).

Local wisdom is the way people behave and act in response to changes in the physical and cultural environment. A conceptual idea that lives in society, grows and develops continuously in people's consciousness, from those related to sacred life to profane ones (daily part of life and its mediocrity). Local wisdom can be understood as local ideas that are wise, full of wisdom, of good value, which are instilled and followed by members of the community (Istiawati 2016, 1). Then, I define wisdom in the perspective of legal philosophy as it relates to the general principles of positive law, the concepts of action, intention, will, freedom, and justice. Apart from that, it also becomes a standard of assessment, namely assessing people's lives by stating what is considered good and bad, as well as instructions on which behavior or actions should be carried out and which must be abandoned.

According to Law Number 32 of 2009 concerning Environmental Protection and Management, local wisdom is the noble values that apply in the order of community life to, among others, protect and manage the environment in a sustainable manner. These various definitions can be given a general understanding that local wisdom is a value and knowledge that local communities and indigenous peoples have from generation to generation from their ancestral heritage to be implemented in their daily life. In the context of environmental management, local communities or indigenous peoples have methods to balance the functions of nature. In the atmosphere of the COVID-19 pandemic, Indonesian indigenous people handle COVID-19 based on local wisdom.

Environmental policy in the perspective of customary law has a different meaning from national environmental policy according to law. Environmental policy according to customary communities or customary environmental law is the whole of principles and rules, both codified and uncodified, which govern the relationship between customary law communities and their environment based on traditional thinking. There are three philosophies of indigenous peoples in environmental management, first, "religious belief or ancestor worship", meaning that the applicable provisions come from God or ancestral spirits that are sacred, and are considered sinful or disobedient if they violate them, and have a negative effect, second, "balance in preserving nature", meaning maintaining a harmonious relationship among the elements of the universe to maintain 
a balance between the natural elements, both in the micro and macro realms or to achieve the safety of all-natural elements; and third, "common", which means that the applicable rules are based on the public interest, namely the universe, including humans in it (Imamulhadi 2016).

Indigenous peoples in Indonesia have their arrangements in local wisdom in environmental management, including protecting the environment from human actions that cause environmental damage. Arizona and Cahyadi explain that the first seeds of the indigenous peoples' movement were sown in the 1980s. Early discussions were initiated by the environmental activists from the Indonesian Forum for Environment Friends of the Earth Indonesia (Wahana Lingkungan Hidup Indonesia, WALHI) and by the legal aid activists from the Legal Aid Foundation of Indonesia (Yayasan Lembaga Bantuan Hukum Indonesia, YLBHI). At the time, these organisations had already started working on the protection of the indigenous peoples whose ancestral lands were being expropriated by the government and turned into mining and forestry concessions under the developmentalist policies of the New Order regime (Hauser-Schäublin 2013).

Culture lies at the core of what in Indonesia is called "adat". Indigenous peoples in Indonesia, apart from their history of oppression and dispossession, ultimately argue with their particular localized "culture" that distinguishes them from others; a specific definition of their cultural particularity is, therefore, required to fill the "tribal slot". The translation AMAN made of "masyarakat adat", which literally means "customary communities", as "indigenous peoples" has to be understood as a possibility to interlink with the transnational indigeneity movements. According to the new law on indigenous peoples that is being discussed in parliament in Indonesia, masyarakat adat needs to display five features for official recognition as "masyarakat hukum adat", customary law community: to have a shared history, to own customary land, to have adat law, to possess specific property relations and inheritance/or adat artefacts, and to have a customary governance system (Hauser-Schäublin 2013). In the Draft Law that was last discussed at the House of Representatives in 2019, the process of recognition in the form of a formal indigenous peoples before obtaining Protection and Empowerment and their rights, the process is carried out by the committee by identifying, verifying, and validating the existence of the indigenous peoples in an area based on the characteristics that have been determined in the law, then its legality will be determined by a regional regulation. Furthermore, the indigenous peoples are entitled to protection of their rights, including rights to customary territories, rights to natural resources, rights to development, rights to spirituality and culture, and rights to the environment.

The term "masyarakat hukum adat" or "adat law" communities is often used by the policymakers, because this term appears recurrently in the legal regulations. The academics also use the same term, because it is a literal translation from "Adat Rechtsgemenschaapen". The masyarakat hukum adat are defined in the RUU PPHMHA (Rancangan Undang-Undang tentang Pengakuan dan Perlindungan Hak-Hak Masyarakat Hukum Adat) as:

a group of people who have been living in a certain geographical area for generations in the territory of the Republic of Indonesia because of the ancestral connection and a 
special relationship with the land, territory and natural resources, who own a customary governance system and an adat law order on their territory. ${ }^{5}$

The Rio Declaration on Environment and Development (principle 22) proclaims indigenous peoples as vital actors in the achievement of sustainable development. Similarly, the Convention on Biological Diversity underscores the important role of indigenous peoples in the use and conservation of biological and genetic resources. This understanding is also reflected in the Report of the World Commission on Environment and Development: Our Common Future (World Commission on Environment and Development 1987, 114-115). It states that indigenous and tribal peoples are, repositories of vast accumulation of traditional knowledge and experience that links humanity with its ancient origin. Their disappearance is a loss for their larger society, which could learn a great deal from their traditional skills in sustainably managing very complex ecological systems (World Commission on Environment and Development 1987).

Besides, indigenous and tribal peoples are making recovery from natural imbalances due to COVID-19. Indigenous people believe that the emergence of COVID-19 is due to an unbalanced and harmonious relationship between humans and living things and their environment. Anthropocentric human behavior tends to conquer nature, in the form of controlling and hunting for biodiversity, both flora and fauna, which are protected by the state. Indigenous peoples carry out various daily activities to manage their natural resources through agriculture, looking for traditional medicines, hunting, and other activities to fulfil family life needs to be based on the traditional calendar as their reference. The knowledge they have is passed down from generation to generation by their ancestors and performs rituals to maintain the balance of the natural environment so that environmental damage or pollution does not occur. All of this is part of customary law, so there is a link between environmental policies in restoring natural balance during the COVID-19 pandemic through local wisdom in handling COVID-19.

In Indonesia, the indigenous people of some areas have a way to fight COVID-19, for example in the Kerinci Jambi indigenous community by sounding a canang when there is a disaster or disease outbreak, then the Kerinci people say the call to prayer in front of their houses for three days. The Orang Rimba, an indigenous community living in the province of Jambi, Indonesia, have a longstanding tradition of enforcing social distancing measures (Azoulay 2020). Tumenggung Tarib, an elder of the Orang Rimba, an Indigenous peoples living inside the Bukit Duabelas National Park in Jambi, Sumatra said: "For hundreds of years, we have been practicing what is called self-quarantine. Long before the recent COVID-19 outbreak. We called it besesandingon", as form of local wisdom to reduce the spread of COVID-19 (Barahamin 2020).

Other than that, they use plants obtained from the natural surroundings as traditional medicine or called ethnobotany. The term "Ethnobotany" refers to all studies that are related to the reciprocal relationship between plants and traditional peoples.

\footnotetext{
5 This definition was agreed upon at the JAPHAMA (Jaringan Pembelaan Hak-hak Masyarakat Adat) meeting in 1993 at Tana Toraja, South Sulawesi. This definition became the working definition of AMAN. On the basis of this definition, the RUU PPHMHA (Rancangan Undang-Undang tentang Pengakuan dan Perlindungan Hak Masyarakat Hukum Adat) proposed the six characteristics of the indigenous peoples mentioned.
} 
Ethnobotany, in general, thus refers to the study about the utilization of plants for a wide variety of humans needs such as medicine, food, fodder, fibre, and goods required for their material culture and amenities (Diame 2010).

Then the people of the Rejang Tribe in Lubuk Kembang Village, Curup Utara District, Rejang Lebong Regency, Bengkulu held a ritual called "Kedurei" to ask for protection from the coronavirus outbreak. The ritual is colored by praying to God and respecting the ancestors in the Rejang language which is carried out in the middle of an unplanted rice field, while people sit in a circle and say a prayer to "God Almighty, we pray a prayer, we also convey to our ancestors at this time in our village under threat, there is a kind of terrible plague attacking Indonesia, namely COVID-19". In the local wisdom of the indigenous people of Yumame Village, Aitinyo District, Maybrat Regency, West Papua, they hold a traditional ritual called "Tah Was" which is believed to be able to expel all diseases including corona (COVID-19). The Maybrat people have practiced this ritual since ancient times. They believe that nature can repel all diseases (Kurniati 2020).

The COVID-19 pandemic serves as a warning from God to greedy and excessive humans in utilizing the environment and natural resources available on earth. An anthropocentric perspective has a significant impact on changing human behavior to exploit the available environment on earth in exploitative ways and degrades good environmental quality. Utilizing the environment is a right while preserving it is an obligation. Customary environmental law as a spirit that is explored and applied by humans, especially "humans" as the authorities in environmental and natural resource management policy.

Various concepts about "the balance of nature" and the elements in it as a constant concept in traditional societal structures, the author offers ideas and formulations from existing concepts to be developed continuously by researchers, academics, activists, or environmentalists on the state of the art is a science, especially in the field of environmental law studies during the COVID-19 pandemic by obeying unwritten legal provisions and the original character of the Indonesian people regarding the renewal of the concept of legal cosmology. This concept is a provision or rule that places nature as the subject of God's creation and as a general human being is a subject to be respected, because nature is a holistic entity, while humans are only the smallest part of the cosmic universe both macro and microcosmic. Humans who are obedient to the Creator of the universe, namely God, not only perform worship according to their religion and/or beliefs, but humans also respect nature as the subject of God's creation that gives life to living things without exception.

One of the forms of local wisdom in managing the environment of the Baduy indigenous people in Lebak Regency, Banten Province in handling COVID-19 carried out various activities based on the customary law previously described, including farming to develop agriculture and meeting their basic needs, hold traditional ritual, customary leadership rules to prohibit leaving the area, and closing tourist attractions. They also perform traditional rituals to "Dewi Padi" or "Nyi Pohaci Sanghyang". Their ricefarming system is very simple because they only recognize cultivation, which is planting rice without using water. Until now, the farming tradition as a livelihood for the Baduy community has not been disturbed by the COVID-19 pandemic. The Baduy people are very wise in preserving the natural surroundings. It is not surprising that the Baduy 
customary area is surrounded by forests and forests are the most important resource for the community (Nugraha 2020).

Balinese culture governed by the Tri Hita Karana concept. Human happiness will be achieved if there are three harmonious relationships. The third element which is the relationship consists of "Parahyangan", "Pawongan", and "Palemahan". Parahyangan is a holy place unit (Pura) that reflects Divinity. Pawongan is a customary community organization unit as the embodiment of elements between fellow humans. Palemahan is in the form of a certain unit or area as the manifestation of elements of the universe or the environment. Parahyangan is a holy place unit (Pura) that reflects Divinity. Pawongan is a customary community organization unit as the embodiment of elements between fellow humans. Palemahan is in the form of a certain unit or area as the manifestation of elements of the universe or the environment. The principle of ecosystems and networks of life that exist and provide each other is highly valued. Humans define the benefits of livestock and forests, livestock forage in forests, and humans maintain forests. If one of the three elements is separated, it will have an impact on the other elements. All tribes and customs in Indonesia have local wisdom that is environmentally friendly. These values are strong assets for environmental conservation efforts. In fact, there are many gaps between these cultural values and daily behavior (Lupiyanto 2020).

Various forms of local wisdom in handling COVID-19 carried out by indigenous peoples show the formation of the cultural identity of the Indonesian nation which is explored based on the local values of the Indonesian people. Customary law communities have wisdom in their behavior, so it needs to be integrated into environmental policy. According to the customary law perspective, the existence of COVID-19 shows an imbalance in the relationship between God as the creator of the universe, fellow living things, and nature itself. Humans carry out recovery through customary ritual mechanisms that are different from each region, unifying between God, humans, and nature, so that the handling of COVID-19 can be done through a partnership between the Indonesian government and indigenous peoples.

State control over natural resources, which is dominated by various formal procedural regulations, has ignored the existence of customary law. In this condition, the position of customary law becomes weak, local wisdom is ignored, and indigenous peoples are not involved in natural resource and environmental management policies, while the problem of COVID-19 is a problem of imbalance in the natural environment and exploitative use of natural resources.

The centralization of law in national development contradicts the fact of pluralism in Indonesian society. For this reason, legal pluralism is an option that should be considered to improve the welfare of society in the field of law, to ensure the integrity of the state. Legal pluralism is understood here as deriving from the recognition of one legal system by another legal system - usually that of the nation state. Keebet von BendaBeckmann calls this a legal political concept of legal pluralism that has developed into what scholars interested in law at the transnational and global level today understand as "normative legal pluralism" (von Benda-Beckmann and Turner 2018, 263). But generally the condition of legal pluralism challenges the exclusiveness and self-evidence of any single normative system. Benda-Beckmann gave a reference example to the rules 
of one system in Indonesia, for example adat over Islam, or state law, then is often political and ideological statement. One does not simply choose a number of rules to apply to a problematic situation, but for the whole (sub) system on which these rules are formed part (von Benda-Beckmann 2002, 69).

The constitutional strengthening of customary law communities and the rights therein, including the right to manage natural resources, in this case, mining, in essence, mining business activities cannot be separated from the social context. In managing the copper and gold mine in Timika Papua, it has been going on for more than 30 years, the issue of customary land which is being cultivated by PT Freeport has become a national political issue that will potentially threaten the protection of customary land in Papua, and the criminalization of indigenous people who defend the customary lands of Papua. It must be admitted that there is a harmony between leading to and realizing the protection of customary land laws in Papua, and the various principles of the welfare state (Suharyo 2019).

3.2. The relationship between environmental management policy and local wisdom of indigenous peoples during the COVID-19 pandemic in Indonesia

Why should environmental protection be treated as a human rights issue? There are several possible answers. Most obviously, and in contrast to the rest of international environmental law, a human rights perspective directly addresses environmental impacts on the life, health, private life, and property of individual humans rather than on other states or the environment in general. It may serve to secure higher standards of environmental quality, based on the obligation of states to take measures to control pollution affecting health and private life. Above all it helps to promote the rule of law in this context: governments become directly accountable for their failure to regulate and control environmental nuisances, including those caused by corporations, and for facilitating access to justice and enforcing environmental laws and judicial decisions. Lastly, the broadening of economic and social rights to embrace aspects of public interest in environmental protection has given new life to the idea that there is or should be, in some form, a right to a decent environment (Boyle 2012).

In environmental management, local wisdom is part of the diversity of Indonesian society, in which there are customary law communities/communities of indigenous peoples who live in sectoral natural resources, both in forest areas, mining areas, as well as coastal and interior areas. Environmental management policy based on Law Number 32 of 2009 concerning Protection and Management of the Environment during the COVID-19 pandemic, a synergy between the government and indigenous peoples is urgently needed.

Customary law communities are indigenous peoples of a customary law fellowship, which since their birth and life are bound and subject to the customary laws in force in the area. The implementation of the basic rights of indigenous peoples needs to be emphasized because their rights have so far been neglected (Nurlinda 2009). The first Indigenous Peoples Congress of the Archipelago in 1999 defined indigenous peoples as communities that live based on their ancestral origins over an indigenous territory, who has sovereignty over land and natural resources, local cultural life, which is governed by customary law. and customary institutions that manage the sustainability of people's 
lives (AMAN 2017). The United Nation Declaration on the Rights of Indigenous Peoples (UNDRIP) was adopted by General Assembly Resolution 61/295 on September 13, 2007, and Indonesia is one of the countries that signed the UNDRIP, so that the Rights of Indigenous Peoples listed in this declaration are binding on Indonesia. morally to recognize, respect, and fulfil the rights of Indigenous Peoples in the territory of Indonesia. UNDRIP provides strong protection for indigenous peoples' rights to natural resources even though it is still a soft law instrument, which is not legally binding. The resolution of problems with customary rights based on UNDRIP is by providing restitution of land to customary law communities and compensation if restitution is not possible (UNDRIP, 2007).

The contribution of indigenous peoples to the environmental management of forest areas is also accommodated by several local governments through the issuance of regional legal products. Based on the identification of data on regional legal products during the period 1979-2017, 53 regional law products contain aspects of environmental management and protection in customary areas and forests. Reducing Emissions from Deforestation and Forest Degradation (REDD), customary forest management, customary forests as buffer zones for conservation areas, and partnership conservation models, are some of the content regulated in the regional legal products (Wicaksono and Malik 2018, 33).

The relationship between the state and indigenous peoples in the management of natural resources has been stated in the Indonesian constitution, the 1945 Constitution of the Republic of Indonesia, and the Decree of the People's Consultative Assembly of the Republic of Indonesia (Ketetapan Majelis Permusyawaratan Rakyat Republik Indonesia - Tap MPR) Number IX / MPR / 2001 concerning Agrarian Reform and Management of Natural Resources, is stated explicitly in Article $4 \mathrm{j}$ that agrarian reform and natural resource management must be implemented following the to recognize, respect, and protect of indigenous peoples rights and cultural diversity nation over agrarian resources/natural resources (Tap MPR 2001). Environmental policy and natural resource management during the COVID-19 pandemic must build partnerships or cooperation between the government and customary law communities spread across some regions in Indonesia.

Environmental policy and natural resource management in the COVID-19 pandemic can be realized through the application of local wisdom, reducing the use of products that produce waste, and not burning forests and land during the COVID-19 pandemic, both individuals, indigenous peoples, and corporations, although in Law Number 32 of 2009 concerning Environmental Protection and Management, communities are allowed to clear land by burning, this provision needs to be re-evaluated and reconsidered for its management so that forests can be protected from fires and can reduce carbon emissions during a pandemic COVID-19.

Carbon emissions were very dangerous during the COVID-19 pandemic because of the uncontrolled space for the community to carry out various activities that produce carbon emissions. Carbon emissions threaten human health during a pandemic, because clean air is very depleted, coupled with the very fast transmission of COVID-19, all of which can threaten human health, especially the respiratory system. Various activities that produce emissions include the use of land, sea and air transportation, the electric power 
sector, the commercial and residential building industry, including industries that utilize natural resources in the forestry and mining sectors. The activities of companies that burn forests and land are reduced during the pandemic, and various other land transportation, so that a country's lockdown policy, regional quarantine, and social restrictions can affect the reduction of carbon emissions during a pandemic. In the long term, changes in individual behavior are needed to achieve a reduction in carbon emissions, so that there is a correlation between a pandemic period in human activities that produce carbon emissions with a threat to human health, when uncontrolled, will be dangerous and worsen the situation.

The philosophy contained in the environmental law from the perspective of indigenous peoples is religious, magic and the balance of nature as a philosophy of Indonesian environmental law which is formed based on a combination of divine, humanitarian, and national unity values so that in its policy, it is necessary to create a partnership between the government and indigenous peoples who live in natural resource areas.

The state controls manage and exploits mining resources that are development-oriented and economic, as well as always protecting indigenous peoples, including having a separate mechanism or method for managing the environment. In the provisions of Article 63 paragraph (1), (2), and (3) Law Number 32 of 2009 concerning Environmental Protection and Management, it provides the government's obligation to establish a policy regarding procedures for recognizing the existence of indigenous peoples, local wisdom, and rights. indigenous peoples related to environmental protection and management.

Mella Ismelina, Professor of Environmental Law from the Faculty of Law Tarumanagara University said that the orientation of environmental law development is ultimately degraded to the lowest point in legal development which only puts forward aspects of legislation and state policy, through a management model that has been regulating and supervising. Environmental law development policy still does not see opportunities for local wisdom values that have a more religious-cosmic relationship regarding the relationship between humans and their environment. The development of environmental law is built based on state domination in the formulation of policy or regulations and their implementation in the field of environmental management (Ismelina 2014, 2073).

Economic development policy still entails the use of natural resources as raw material, in order to foster both national and local development, so the country uses an anthropocentrism approach in managing the environment and natural resources. The environment is not only a conservation and preservation function but the environment as a commodity and object that can generate economic/profit. During the COVID-19 pandemic, environmental policy in Indonesia's development should consider environmental, social, and cultural aspects, including how to manage natural resources that do not damage the ecosystem and lead to transmission of the COVID-19 virus from hunted wild animals by humans for economic/business purposes. Indonesian indigenous peoples have close relationships with other living things to protect and protect each other, including ecosystems in forest areas, both flora, and fauna. Besides that, for the community that utilizes natural resources to support economic activities or private sector users to be more prudent in utilizing the availability of the environment 
for economic activities, also pay more attention to environmental aspects that are balanced and well maintained (Caraka et al. 2020, 66).

Community involvement and community empowerment in environmental development and management have not been maximized so that the management and development system for environmental law is not participatory and holistic. Furthermore, it is said that the policy formulated is not in line with the potential of environmental resources and society. Such conditions make environmental law not yet accommodating the resolution of environmental problems that occur in society, providing welfare to society as a whole, and unable to provide a balance between social justice and ecological justice. The purpose of the role of the community is to increase awareness in environmental protection and management, increase independence, community empowerment, and partnerships, develop community skills and initiatives, develop community responsiveness to carry out social supervision; and developing and maintaining local culture and wisdom to preserve environmental functions (Kahfi 2015, 50). During the COVID-19 pandemic, environmental management through the local wisdom of indigenous peoples can be integrated into Indonesian policy and laws.

The COVID-19 problem should be seen as a global problem that is seriously handled by world leaders, each country commits to handling COVID-19, such as environmental problems as a global problem for humanity worldwide. Satjipto Rahardjo, an Indonesian legal figure who is very popular with Indonesia's progressive legal thinking from the Faculty of Law, Diponegoro University, has opened the perspective of Indonesian law enforcement officers to not only think positivistic-dogmatically in carrying out laws and regulations. He said that humans need to understand life in the universe which has the relationship between living things, and among these ecosystem communities nothing should interfere with their life for the sake of survival in the universe. Satjipto Rahardjo's idea was inspired by Capra's thought in understanding the universe of life. An understanding of these problems gives a message that the law can adapt to life in the universe and does not damage the relationships of ecosystem communities in the universe (Rahardjo 2009, 14).

From the customary legal point of view, the emergence of COVID-19 is a disruption of life in the universe caused by an imbalance in the relationship between communities of living things on earth as a single ecosystem. Human activities and economic development by utilizing natural resources are very exploitative towards ecosystem communities in nature, resulting in natural imbalances. Indigenous peoples in Indonesia recover from this natural imbalance through traditional rituals as previously described. From the activist perspective, humans are anthropocentric to dominate the earth and the natural resources in it, resulting in damage to the environment and the universe, and the extinction of biodiversity only to meet pragmatic needs and economic interests in national development policies. The state ignores indigenous peoples and local wisdom therein and carries out economic development while ignoring environmental sustainability.

Ida Nurlinda, Professor of the Agrarian and Environmental Law, Faculty of Law Padjadjaran University and Chair of the Indonesian Environmental Law Trustees Association (Asosiasi Pembina Hukum Lingkungan Indonesia), she said observes that development policy in Indonesia has so far been growth-oriented which has put 
economic development in a more important position than development in other fields. This shows that so far Indonesia has not implemented sustainable development because there is no balance in the implementation of development between the economic, social, and environmental conservation sectors (Nurlinda 2009). To balance the existence of natural resources with economic activities, environmentally sound development is required. The embodiment of harmonization between economic development and environmental conservation and resources are two main things that need to be considered (Rosana 2018).

The country's paradigm has a tremendous impact on social life and the environment. The leaders of the world were driven to adopt a new development paradigm, focused not only on economy. Sustainable development was introduced as a global priority in the so-called "Earth Summit," in Rio de Janeiro, in 1992. Then, in 2002 and 2012 most of the world's countries refreshed their commitments to achieve sustainability. Sustainable development consists of three pillars: economic development, social development, and environmental protection (Katsoulakos 2016). For example, the reduction or even loss of access of customary/local communities to land and agrarian resources around their territory, due to oil palm plantations or oil refinery drilling. Besides, the author provides an example in the context of mining business activities that destroy the environment, leave mining pits, and mining areas overlap with indigenous peoples' territories or lands, so that the potential for social conflict is very large, in addition to destroying the wisdom of indigenous peoples in environmental conservation.

Indigenous peoples have a long history of mobilizing together on the global level. At the United Nations, indigenous delegates appeared in 1977 to speak "on behalf of those that do not have a voice" - nature and the future generations, and to protest against the destruction of their territories, resources and cultures. In 1982, an ECOSOC decision established the United Nations Working Group on Indigenous Populations (WGIP). When indigenous groups started lobbying the UNCED process a decade later, their primary goal was not to get a separate chapter on indigenous peoples, but to ensure that all chapters of Agenda 21 would include perspectives and issues relevant to indigenous peoples. This resulted in indigenous concerns being mentioned in several paragraphs throughout the text. However, it is a major weakness from the indigenous perspective that Agenda 21 and other Rio documents still operate within the framework of the dominant development paradigm, instead of questioning the economic growth model as the main reason for environmental degradation (Stakeholder Forum for a Sustainable Future 2012, 258).

Environmental and natural resource policies carried out by the state and indigenous peoples require a cooperative relationship about land issues or the use of land rights. Wahyu Nugroho conducted an empirical study on land issues related to natural resources, the forestry sector, mining, industry, and plantations have experienced changes in the legal order in interacting with the policy in the field of natural resources, so that conflicts between state laws and customary law, or even competition between these legal systems in accessing natural resources in various sectors, or economic, social and cultural rights, as well as collective rights which are the rights of indigenous peoples (Nugroho 2015, 203). 
The legal anthropological approach is essential to the recognition and protection of indigenous peoples and the objects of land rights in the 1945 Constitution comprehensively as a constitutional basis in the management of natural resources (Nurjaya 2015, 52). Therefore, local governments can place customary law as living law as part of national law, and policymakers direct it to a historical interpretation at the time the provisions concerning regional autonomy and customary law communities were born into the regional government chapter.

Environmental management in Indonesia during the COVID-19 pandemic, if it is effective as a reflection of the relationship between ecological communities, will give birth to ecological balance or in legal terms, it is called ecological justice. The concept of environmental justice can be said to be a new concept in the conceptual discourse of justice. In some Indonesian literature, there are still only a few reviews on ecological justice, but if we trace various sources from foreign literature, many have discussed or written about ecological justice, regardless of whether it is at the conceptual level or the stage of implementation. One of the triggers for the birth of environmental justice is the emergence of various symptoms of natural destruction, especially after the industrial revolution (Binawan and Sebastian 2012).

\section{Conclusion}

Based on the description of the discussion and analysis, the conclusions are first, constructing local wisdom of Indonesian indigenous peoples in environmental management and handling of COVID-19, based on the teachings of their ancestors. They carry out various natural resource management activities to meet their family's needs based on the customary calendar as their reference. These various local wisdoms are one of the ways to deal with the COVID-19 pandemic. Second, the relationship between environmental management policy and local wisdom of indigenous peoples during the COVID-19 pandemic in Indonesia uses the philosophy and principles of customary environmental law as a philosophy of Indonesian environmental law which is formed based on a combination of the divine, humanitarian, and unity values, so that in its policy, partnerships need to be made between the government and indigenous peoples living in natural resource areas. Environmental management policies consider the balance of nature and changes in human behavior through forms of local wisdom in various activities to reduce carbon emissions during the COVID-19 pandemic.

\section{References}

Alfian, M., 2013. Potensi Kearifan lokal dalam Pembentukan Jati Diri dan Karakter Bangsa. Prosiding The 5 thn ICSSIS; Ethnicity and Globalization [online]. Yogyakarta, 13-14 June. Available from: https://icssis.files.wordpress.com/2013/09/2013-01-33.pdf [Accessed 2 October 2020].

Aliansi Masyarakat Adat Nusantara (AMAN), 2017. Mengapa Indonesia Memerlukan UU Pengakuan dan Perlindungan Hak Masyarakat Adat? [online]. Available from: https://www.aman.or.id/wp-content/uploads/2017/04/Mengapa-IndonesiaMemerlukan-UU-Masyarakat-Adat.pdf [Accessed 4 February 2021].

Arizona, Y., 2014. Masyarakat Adat, Masyarakat Hukum Adat dan Desa Adat. Presentasi, Balikpapan 27-28 Maret. 
Atmadja, I.D.G., 2006. Hukum Konstitusi, Perubahan Konstitusi dari sudut Pandang Perbandingan. Denpasar: Bali Aga.

Azoulay, A., 2020. Foreword. Indigenous Peoples and the COVID-19 pandemic. UNESCO Indigenous Peoples Bulletin [online], $\mathrm{n}$ - 1. Available from: https://en.unesco.org/news/indigenous-peoples-and-covid-19pandemic\#foreword [Accessed 7 February 2021].

Barahamin, A., 2020. Dignified quarantine: indigenous strategies for containing COVID-19 in Indonesia. New mandala [online], 28 May. Available from: https://www.newmandala.org/dignified-quarantine-indigenous-strategies-forcontaining-covid-19-in-indonesia/ [Accessed 7 February 2021].

Binawan, A.A., and Sebastian, T., 2012. Menim(b)ang Kedilan Eko-Sosial. Kertas Kerja No. 07. Jakarta: Epistema Institute.

Boyle, A., 2012. Human Rights and the Environment: Where Next? The European Journal of International Law [online], 23(3), 613-614. Available from: https://doi.org/10.1093/ejil/chs054 [Accessed 7 February 2021].

Caraka, R.E., et al., 2020. Impact of COVID-19 large scale restriction on environment and economy in Indonesia. Global Journal of Environmental Science and Management (GJESM) [online], 6(Special Issue). Available from: https://dx.doi.org/10.22034/GJESM.2019.06.SI.07 [Accessed 7 February 2021].

Choe, H., and Yun, S.J., 2017. Revisiting the Concept of Common Pool Resources: Beyond Ostrom. Development and Society, 46(1), 113-129.

De Lucia, V., 2017. Beyond anthropocentrism and ecocentrism: a biopolitical reading of environmental law. Journal of Human Rights and the Environment [online], 8(2). Available from: https://doi.org/10.4337/jhre.2017.02.01 [Accessed 7 February 2021].

Diame, G.L.A., 2010. Ethnobotany and Ecological Studies of Plants Used for Reproductive Health: A Case Study at Bia Biosphere Reserve in the Western Region of Ghana [online]. Final report submitted to The Division of Ecological Sciences, UNESCO (MAB) Young Scientist Research Award Scheme. Accra: UNESCO. February. Available from: http://www.unesco.org/science/doc/mab/MAB Ghana2008.pdf [Accessed 7 February 2021].

Fajarini, U., 2014. Peranan Kearifan Lokal Dalam Pendidikan Karakter. Jurnal Sosio Didaktika [online], 1(2), 123-130. Available from: https://doi.org/10.15408/sd.v1i2.1225 [Accessed 7 February 2021].

Forsyth, T., and Johnson, C., 2014. Elinor Ostrom's Legacy: Governing the Commons and the Rational Choice Controversy. Development and Change [online], 45(5), 1093-1110. Available from: https://doi.org/10.1111/dech.12110 [Accessed 7 February 2021].

Hauser-Schäublin, B.H., ed., 2013. Adat and Indigeneity in Indonesia Culture and Entitlements between Heteronomy and Self-Ascription. Göttingen Studies in Cultural Property [online], vol. 7. Available from: 
https://ibrary.oapen.org/bitstream/id/77c8a98b-5e0b-4be3-ba254753f4f9a8c0/610301.pdf [Accessed 6 February 2021].

Imamulhadi, 2016. Hukum Lingkungan Alternatif: Hukum Lingkungan Adat, Hukum Lingkungan Islam. Yogyakarta: K-Media.

Iskandar, 2011. Konsepsi dan Pengaturan Hak atas Lingkungan Hidup yang Baik dan Sehat (Kajian Perspektif Hak Asasi Manusia dalam Pengelolaan Lingkungan Hidup) [online]. Fakultas Hukum Universitas Bengkulu. Available from: http://repository.unib.ac.id/7803/1/Jurnal\%20Bengkoelen\%20Justice.pdf [Accessed 7 February 2021].

Ismelina, M., 2014. Model Pemberdayaan Hukum Lingkungan Religius-Kosmik sebagai Upaya Pelestarian Fungsi Lingkungan Hidup. Litigasi Jurnal Ilmu Hukum [online], 15(1). Available from:

http://dx.doi.org/10.23969/litigasi.v15i1,http://journal.unpas.ac.id/index.php/litiga si/article/view/71 [Accessed 7 February 2021].

Istiawati, N.F., 2016. Pendidikan Karakter Berbasis Nilai-Nilai Kearifan Lokal Adat Ammatoa dalam Menumbuhkan Karakter Konservasi. Cendekia Jurnal Pendidikan dan Pembelajaran [online], 10(1). Available from: https://doi.org/10.30957/cendekia.v10i1.78 [Accessed 7 February 2021].

Jazuli, A., 2015. Dinamika Hukum Lingkungan Hidup dan Sumber Daya Alam dalam Rangka Pembangunan Berkelanjutan. Jurnal Rechtsvinding [online], 4(2), 187. Available from: https://doi.org/10.33331/rechtsvinding.v4i2.19 [Accessed 7 February 2021].

Kahfi, A., 2015. Peran Serta Masyarakat Dalam Pengelolaan Lingkungan Hidup. Jurisprudentie [online], 2(2). Available from: http://journal.uinalauddin.ac.id/index.php/Jurisprudentie/article/view/4003 [Accessed 7 February 2021].

Katsoulakos, N.M., 2016. Environment and Development, basic principles, human activities, and environmental implications. In: S.G. Poulopoulos and V.J. Inglezakis, eds., Environment and Development. Edinburg/London/Oxford/Amsterdam: Elsevier, 499-569.

Ketetapan Majelis Permusyawaratan Rakyat Republik Indonesia (Tap MPR), 2001. Nomor IX/MPR/2001 tentang Pembaruan Agraria dan Pengelolaan Sumber Daya Alam.

Kurniati, P., ed., 2020. Ritual-ritual Tolak Bala Usir Corona di Berbagai Daerah, Bunyikan Canang hingga Cukur Gundul. Kompas.com [online], 2 April. Available from: https://regional.kompas.com/read/2020/04/02/06150051/ritual-ritual-tolakbala-usir-corona-di-berbagai-daerah-bunyikan-canang?page=all [Accessed 1 October 2020].

Law Number 32 of 2009 concerning Environmental Protection and Management.

Lupiyanto, R., 2020. Wabah Corona, Bencana Kesehatan dan Mitigasi Ekologi Budaya. Mongabay [online], 11 February. Available from: 
https://www.mongabay.co.id/2020/02/11/wabah-corona-bencana-kesehatan-danmitigasi-ekologi-budaya/ [Accessed 26 October 2020].

Nugraha, A.S., 2020. Kearifan Lokal dalam Menghadapi Pandemi COVID-19: Sebuah Kajian Literatur. Sosietas Jurnal Pendidikan Sosiologi [online], 10(1), 745-753. Available from: https://doi.org/10.17509/sosietas.v10i1.26063 [Accessed 7 February 2021].

Nugroho, W., 2015. Reorientasi Kebijakan Pemerintah Daerah dalam Penerapan Otonomi Daerah di Bidang Pertanahan dan Penataan Ruang. Jurnal Legislasi Indonesia [online], 12(2). Available from: https://ejurnal.peraturan.go.id/index.php/jli/article/view/406 [Accessed 7 February 2021].

Nurjaya, I.N., 2015. Is the Constitutional and Legal Recognition of Traditional Community Laws within the Multicultural Country of Indonesia a Genuine or Pseudo Recognition? Constitutional Review [online], 1(2). Available from: https://doi.org/10.31078/consrev123 [Accessed 7 February 2021].

Nurlinda, I., 2009. Prinsip-Prinsip Pembaruan Agraria, Perspektif Hukum. Jakarta: Rajawali Pers.

Ostrom, E., 1990. Governing the Commons. Cambridge University Press.

Priambodo, B.B., 2018. Positioning Adat Law in Indonesia's Legal System: Historical Discourse and Current Development on Customary Law. Udayana Journal of Law and Culture [online], 2(2). Available from: https://doi.org/10.24843/UJLC.2018.v02.i02.p02 [Accessed 7 February 2021].

Rahardjo, S., 2009. Lapisan-Lapisan Dalam Studi Hukum. Malang: Bayumedia.

Rosana, M., 2018. Kebijakan Pembangunan Berkelanjutan yang Berwawasan Lingkungan di Indonesia. Jurnal Kelola: Jurnal Ilmu Sosial [online], 1(1), 154-155. Available from: https://journal.uinsgd.ac.id/index.php/kelola/article/view/4128 [Accessed 7 February 2021].

Simarmata, R., and Steni, B., 2017. Masyarakat Hukum Adat Sebagai Subjek Hukum: Kecakapan Hukum Masyarakat Hukum Adat dalam Lapangan Hukum Privat dan Publik. Bogor: Cet. I, The Samdhana Institute.

Sinapoy, M.S., 2018. Kearifan Lokal Masyarakat Adat Suku Moronene dalam Perlindungan dan Pengelolaan Lingkungan Hidup. Halu Uleo Law Review [online], 2(2), 518-519. Available from: https://doi.org/10.33561/holrev.v2i2.4513 [Accessed 7 February 2021].

Stakeholder Forum for a Sustainable Future, 2012. Sustainable Development in the 21st Century (SD21) Review of implementation of Agenda 21 and the Rio Principles Detailed review of implementation of Agenda 21 [online]. United Nations Department of Economic and Social Affairs Division for Sustainable Development, January. Available from: https://www.un.org/esa/dsd/dsd_sd21st/21_pdf/Study 1 Agenda 21.pdf [Accessed 20 October 2020]. 
Suharyo, 2019. Perlindungan Hukum Pertanahan Adat di Papua dalam Negara Kesejahteraan. Jurnal Rechtsvinding [online], 8(3), 461-476.

https://doi.org/10.33331/rechtsvinding.v8i3.330 [Accessed 7 February 2021].

United Nations Declaration on the Rights of Indigenous Peoples (UNDRIP), 2007. Resolution adopted by the General Assembly on September 13 [online]. Available from: https://www.un.org/development/desa/indigenouspeoples/wpcontent/uploads/sites/19/2018/11/UNDRIP E web.pdf [Accessed 4 February 2021].

von Benda-Beckmann, F., 2002. Who's Afraid of Legal Pluralism? The Journal of Legal Pluralism and Unofficial Law [online], 34(47). Available from: https://doi.org/10.1080/07329113.2002.10756563 [Accessed 7 February 2021].

von Benda-Beckmann, K., and Turner, B., 2018. Legal Pluralism, Social Theory, and the State. The Journal of Legal Pluralism and Unofficial Law [online], 50(3). Available from: https://doi.org/10.1080/07329113.2018.1532674 [Accessed 7 February 2021].

Wicaksono, M.T., and Malik, M., 2019. Konteks Politik Hukum Dibalik Percepatan Penetapan Hutan Adat: Catatan ke Arah Transisi. Jurnal Hukum Lingkungan Indonesia [online], 4(2). Available from: http://dx.doi.org/10.38011/jhli.v4i2.60 [Accessed 7 February 2021].

World Commission on Environment and Development, 1987. Report of the World Commission on Environment and Development: Our Common Future [online]. Available from:

https://sustainabledevelopment.un.org/content/documents/5987our-commonfuture.pdf [Accessed 7 February 2021].

Yusa, I.G., and Hermanto, B., 2018. Implementasi Green Constitution di Indonesia: Jaminan Hak Konstitusional Pembangunan Lingkungan Hidup Berkelanjutan. Jurnal Konstitusi [online], 15(2). Available from: https://doi.org/10.31078/jk1524 [Accessed 7 February 2021]. 